\title{
Antimicrobial activity of medicinal plants against oral Microorganisms
}

\author{
G. More, T.E. Tshikalangea, N. Lall , F. Botha, J.J.M. Meyer \\ Department of Plant Science, University of Pretoria, Pretoria 0002, South \\ Africa \\ Division of Stomatological Research, Department of Community Dentistry \\ School of Dentistry, \\ University of Pretoria, Pretoria 0002, South Africa
}

\author{
Keywords: \\ Antimicrobial \\ Medicinal plants \\ Oral microorganisms \\ Periodontal disease
}

\begin{abstract}
Ethanol extracts of eight plant species used traditionally in South Africa for the treatment of oral diseases were investigated for in vitro antimicrobial activity against oral pathogens namely Actinobacillus actinomycetemcomitans, Actinomyces naeslundii, Actinomyces israelii, Candida albicans, Porphyromonus gingivalis, Privotella intermedia and Streptococcus mutans using the disk diffusion method. Minimum inhibitory concentration (MIC) and minimum bactericidal concentration (MBC) of ethanol extracts were determined against these microorganisms using micro dilution. The cytotoxicity and therapeutic index (TI) of selected active extracts were also determined. Out of eight plants, six (Annona senegalensis, Englerophytum magalismontanum, Dicerocarym senecioides, Euclea divinorum, Euclea natalensis, Solanum panduriforme and Parinari curatellifolia) exhibited MIC values ranging from $25.0 \mathrm{mg} / \mathrm{ml}$ to $0.8 \mathrm{mg} / \mathrm{ml}$. Gram negative bacteria were found to be more resistant to the plant extracts than Gram positive bacteria, except for Euclea natalensis which inhibited all three Gram negative bacteria tested in this study. All plant extracts showed moderate cytotoxicity on the Vero cell line. The fifty percent inhibitory concentration (IC50) of all plants tested range from 92.3 to $285.1 \mu \mathrm{g} / \mathrm{ml}$.
\end{abstract}

\section{Introduction}

Periodontal diseases and dental caries are two main common dental pathologies affecting humankind (Marsh and Martin, 1992). These conditions are caused by plaque forming bacteria and yeast, which reside in the oral cavity. Periodontal diseases have mainly been associated with Actinomyces, Actinobacillus, Streptococcus and Candida species (Van Oosten et al., 1987). Candida albicans is not cariogenic, but was included in this study because it is a pathogenic microorganism causing oral thrush particularly in immunocompromised individuals (Samaranayake, 2000).

Dental treatment usually is expensive and not so easily accessible, especially in developing countries, therefore humans have turned to the use of tooth sticks/chewing sticks to prevent dental caries (Akpata and Akinrimisi, 1977; Homer et al., 1990).

Some of these remedies include bisguanide-antiseptics, quaternary ammonium-antiseptics, phenolic-antiseptics and other remedies such as oxygenating agents, and metal ions (Addy, 1986). Common side effects of some these may be the staining of the teeth and restorations, taste of food and a burning sensation at the tip of the tongue (Gründermann et al., 2000). The use of plants has been closely associated with dental hygiene and therapeutic practices since time immemorial. Chewing sticks are used by the many people in various African tribes such as Namibians, Zimbabweans, Vhavenda and Ethiopians (Olsson, 1978; Lewis, 1980; Mabogo, 1990). Ndukwe et al. (2004) conducted a study investigating the antibacterial activity of chewing stick, his study confirms that chewing sticks have a potential preventing oral ailments. A majority of the plants tested in his study reveals that chewing sticks are capable to inhibit Gram-positive and negative bacteria such as Bacillus subtilis, Porphyromonus gingivalis and Fusobactrium nucleatum. Several African tribes use the common traditional 
chewing stick called 'Muthala', scientifically known as Diospyros lysioides DESF (Khan, 1978) and/or Euclea natalensis A.D.C. (Lall and Meyer, 2000). The use of medicinal plants belonging to the family of Fabaceae, Ebenaceae, Bombaceae and Anonnaceae has been reported for treatment of oral diseases (Hadissa and Jean-Pierre, 2005).

The rationale of this study was to determine the antimicrobial activity of the traditional South African medicinal plants used as chewing sticks against oral microorganisms which are responsible for dental caries. Chewing sticks with antimicrobial activity could become a potential source of new drugs for oral diseases.

Oral microorganisms are known for their pathogenesis in tooth decay, gingivitis, periodontitis and their ability to cause teeth loss (Samaranayake, 2000).

\section{Materials and methods}

\subsection{Plant material}

Different plant parts (twigs, leaves, bark and roots) from eight plant species commonly used in the Venda region (Limpopo Province of South Africa) for various tooth problems such as gingivitis, periodontitis and teeth decay were collected during March 2006. Voucher specimens were prepared and identified at the H.G.W.J. Schwelcherdt Herbarium (PRU), University of Pretoria (Table 1).

\subsection{Preparation of extracts}

The plant material was air dried at $25{ }^{\circ} \mathrm{C}$ and ground in a Junke and Kunkel grinder to a fine powder. The powdered material $(20 \mathrm{~g})$ was extracted with $200 \mathrm{ml}$ of ethanol at room temperature for $48 \mathrm{~h}$. Extracts were filtered and the solvent was evaporated on the rotary evaporator under reduced pressure at $40{ }^{\circ} \mathrm{C}$. The extracts were further dried at room temperature after which they were subjected to antimicrobial tests.

\subsection{Antimicrobial activity}

\subsubsection{Microbial strains}

The microorganisms used in this study included Actinomyces naeslundii (ATCC 19039), Actinomyces israelii (ATCC 10049), Actinobacillus actinomycetemcomitans (ATCC 33384), Candida albicans (Med I), Porphyromonus gingivalis (ATCC 33277), Privotella intermedia

(ATCC 25611) and Streptococcus mutans (ATCC 25175). Bacteria were grown in the Caseinpeptone Soy Agar medium (CASO) (Merck SA (Pty) Ltd.) under anaerobic conditions in an anaerobic jar with an aerocult A (Merck SA (Pty) Ltd.), at $37{ }^{\circ} \mathrm{C}$ for $72 \mathrm{~h}$. Sabouraud Dextrose Agar medium (SDA) (Merck SA (Pty) Ltd.) was used for the culturing of Candida albicans and incubated at $25{ }^{\circ} \mathrm{C}$ for $24 \mathrm{~h}$ under aerobic conditions. Sub-culturing was done once weekly.

\subsubsection{Disc diffusion method}

The microbial growth inhibitory potential of the extracts was determined by using the agar disc diffusion method as described by Washington (1981). Inocula were prepared by mixing a few microbial colonies with sterile ringer's solution and comparing the turbidity with that of the standard 0.5 McFarland solution (McFarland, 1907) which is equivalent to $10^{6}-10^{8} \mathrm{CFU} / \mathrm{ml}$. One hundred microlitres of inocula of all tested microorganisms were inoculated on Caseinpeptone Soy Agar medium for bacteria and Sabouraud Dextrose Agar medium for Candida albicans was used.

Extracts were dissolved in 10\% DMSO (Merck SA (Pty) Ltd.) to a final concentration of $100 \mathrm{mg} / \mathrm{ml}$. Twenty microlitres $(2 \mathrm{mg} / \mathrm{disc})$ and thirty microlitres $(3 \mathrm{mg} / \mathrm{disc})$ of the plant extracts was transferred onto sterile filter papers (5mmdiameter). One hundred microlitres of positive drug control (chlorhexidine 5\%) and 10\% DMSO (solvent control) soaked on filter papers severed as positive and negative control, respectively. The plates were then incubated at $37{ }^{\circ} \mathrm{C}$ for $48 \mathrm{~h}$ anaerobically except for Candida albicans which was incubated at $25^{\circ} \mathrm{C}$ for $48 \mathrm{~h}$. All tests were performed in triplicate and zones of inhibition were measured from the edge of each disc after the incubation period.

2.4. Determination of minimum inhibitory concentration (MIC) and minimum bactericidal concentration $(M B C)$

Although the results of the disc diffusion assay cannot always compare to the MIC data (Njenga et al., 2005), six plant extracts which showed positive antimicrobial activity against 
most of the microorganisms tested in the disc diffusion bioassay were further tested for the determination of minimum inhibitory concentration (MIC) and minimum bactericidal concentration (MBC). The microdilution technique using 96-well micro-plates, as described by Eloff (1998) was used to obtain the MIC and MBC values of the crude extracts against the microorganisms under study. Selected extracts were serially diluted in the 96-well plate with $48 \mathrm{~h}$ old microorganisms $(0.3 \mathrm{CFU} / \mathrm{ml})$ grown at $37{ }^{\circ} \mathrm{C}$ and the final concentration of extracts and positive control (CHX) ranged from $25.0 \mathrm{mg} / \mathrm{ml}$ to $0.8 \mathrm{mg} / \mathrm{ml}$.

Microbial growth was indicated by adding $40 \mu \mathrm{l}$ of $(0.2 \mathrm{mg} / \mathrm{ml}) p$-iodonitrotetrazolium violet (INT) (Sigma-Aldrich, South Africa) to micro-plate wells and incubated at $37{ }^{\circ} \mathrm{C}$ for $48 \mathrm{~h}$. The MIC was defined as the lowest concentration that inhibited the colour change of INT. The MBC was determined by adding $50 \mu$ l of the suspensions from the wells, which did not show any growth after incubation during MIC assays, to $150 \mu$ l of fresh broth. These suspensions were reincubated at $37{ }^{\circ} \mathrm{C}$ for $48 \mathrm{~h}$. The MBC was determined as the lowest concentration of extract which inhibited $100 \%$ growth of microorganisms (Cohen et al., 1998).

\subsection{Determination of cytotoxicity}

\subsubsection{Cytotoxicity assay}

A microtiter plate with Vero cells were used for testing all the ethanol extracts for cytotoxicity following the method of Zheng et al. (2001). Cytotoxicity was measured by the XTT (sodium 3'-[1-(phenyl amino-carbonyl)-3,4-tetrazolium]-bis-[4-methoxy-6-nitro) benzene sulfonic acid hydrate) method using the cell proliferation kit II (Roche Diagnostics $\mathrm{GmbH}$ ). Hundred microlitres of Vero cells $\left(1 \times 10^{5} \mathrm{ml}\right)$ was seeded onto a micro-plate and incubated for $24 \mathrm{~h}$ to allow the cells to attach to the bottom of the plate. Dilution series were made of the extracts and the various concentrations $(400-3.1 \mu \mathrm{g} / \mathrm{ml})$ were added to the micro-plate and incubated for $48 \mathrm{~h}$. The XTT reagents were added to a final concentration of $0.3 \mathrm{mg} / \mathrm{ml}$ and the cells were incubated for $1-2 \mathrm{~h}$.

The positive drug control (Zelaralenone) at concentrations range of $(10-0.6 \mu \mathrm{g} / \mathrm{ml})$ was included in the assay. After incubation the absorbance of the colour was spectrophotometrically quantified using an ELISA plate reader, which measured the optical density at $490 \mathrm{~nm}$ with a reference wavelength of $690 \mathrm{~nm}$. The assay was carried out in triplicate.

Table 1

Plants collected used as chewing sticks

\begin{tabular}{|c|c|c|c|c|}
\hline Plants & Plant family & Plant part number & Voucher specimen & $\begin{array}{l}\text { Medicinal use and } \\
\text { references }\end{array}$ \\
\hline Annona senegalensis Pers. & Annonaceae & Bark & PRU 074974 & $\begin{array}{l}\text { Toothache, venereal, Diarrhoea } \\
\text { (Mabogo, 1990) }\end{array}$ \\
\hline $\begin{array}{l}\text { Ennglerophytum } \\
\text { magalismontanum (Sond.) } \\
\text { T.D. Penn. }\end{array}$ & Sapotaceae & Bark & PRU 095683 & $\begin{array}{l}\text { Pains, contraceptive } \\
\text { rheumatism, Edible } \\
\text { (Hutchings et al., 1996) }\end{array}$ \\
\hline $\begin{array}{l}\text { Dicerocarym senecioides } \\
\text { (Klotzsch) Abels. }\end{array}$ & Pedaliaceae & Roots & PRU 095681 & $\begin{array}{l}\text { Soap substitute, expulsion of } \\
\text { placenta (Van Wyk and Gericke, } \\
\text { 2000) }\end{array}$ \\
\hline Euclea divinorum Hiern & Ebenaceae & Bark, Leaves & \multicolumn{2}{|c|}{$\begin{array}{r}\text { PRU } 095682 \text { PRU 095685Toothache, headache (Mabogo, } \\
\text { 1990; Hutchings et al., 1996) }\end{array}$} \\
\hline Euclea natalensis A.DC. & Ebenaceae & Leave s & PRU 095686 & $\begin{array}{l}\text { Laxative, toothache, epilepsy, } \\
\text { gonorrhea, Kidney calculi } \\
\text { (Mabogo, 1990) }\end{array}$ \\
\hline Erythrina lysistemon Hutch. & Fabaceae & Bark & PRU 066798 & $\begin{array}{l}\text { Toothache, ornamental, wounds } \\
\text { (Mabogo, 1990) }\end{array}$ \\
\hline $\begin{array}{l}\text { Parinari curatellifolia } \\
\text { Planch. Ex Benth }\end{array}$ & Chrysobalanceae & Bark & PRU 096215 & $\begin{array}{l}\text { Toothache, ornamental } \\
\text { (Mabogo, 1990) }\end{array}$ \\
\hline $\begin{array}{l}\text { Solanum panduriforme } \\
\text { E.Mey. }\end{array}$ & Solanaceae & Roots & PRU 090203 & $\begin{array}{l}\text { Pelvic pains, wounds, toothache } \\
\text { (Hutchings et al., 1996) }\end{array}$ \\
\hline
\end{tabular}


Table 2

Antimicrobial activity of plants tested against oral microorganisms with zones of inhibition in millimetre of the extracts and Chlorhexidine

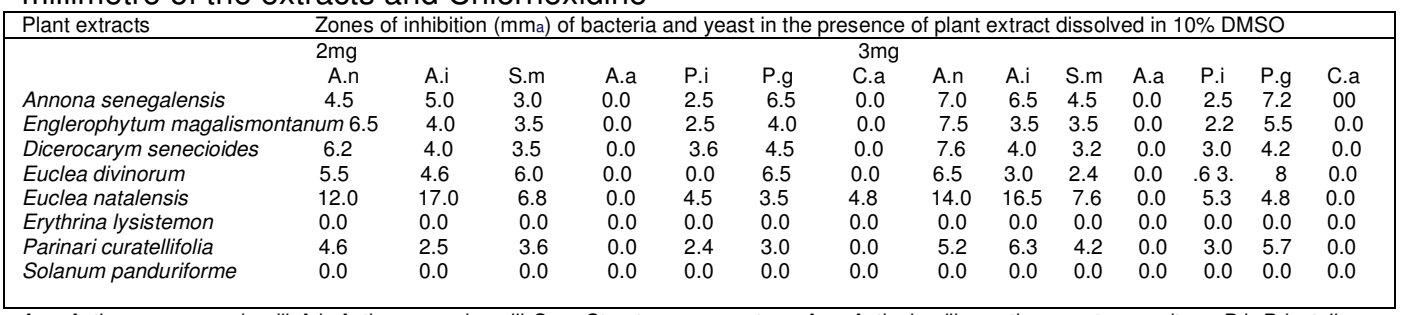

Actinomyces naeslundii: A.i, Actinomyces israelii: S.m, Streptococcus mutans; A.a, Actinobacillus actinomycetemcomitans; P.i, Privotella

intermedia; P.g, Porphyromonus gingivalis; C.a, Candida albicans.

a Diameter of inhibition zone including disc diameter of $5.0 \mathrm{~mm}$.

\section{Results and discussion}

The extracts of Annona senegalensis, Englerophytum magalismontanum, Dicerocarym senecioides, Euclea divinorum, Euclea natalensis and Parinari curatellifolia showed positive inhibitory activity against five microorganisms (Actinomyces naeslundii, Actinomyces israelii, Porphyromonus gingivalis, Privotella intermedia and Streptococcus mutans) at both 2 and $3 \mathrm{mg}$ per disc (Table 2). Euclea natalensis showed inhibition of Actinomyces israelii and Actinomyces naeslundii with zone of $16-17 \mathrm{~mm}$. When Porphyromonus gingivalis was exposed to the extract of Euclea natalensis, 3.5 and $4.8 \mathrm{~mm}$ of zones of inhibition were observed. Of all the microorganisms, Actinobacillus actinomycetemcomitans and Candida albicans were found to be resistant to all the extracts at the highest concentration tested.

The study conducted by Khan et al. (1978) confirms the antimicrobial activity of the bark extracts of Euclea natalensis on Streptococcus mutans and Candida albicans at a concentration of $100 \mathrm{mg} / \mathrm{ml}$. However, the zones of inhibition in the present study were not very prominent when compared with those of chlorhexidine (positive control). Annona senegalensis also exhibited activity against Staphylococcus aureus with zone of inhibition of $18 \mathrm{~mm}$ and $16 \mathrm{~mm}$ for both water and methanol extracts, respectively, but was not active against Escherichia coli a Gram-negative bacterium (Lino and Deogracious, 2006) (Table 3).

The plant extracts which demonstrated excellent results, were selected for MIC, MBC and cytotoxicity determination. Actinomyces naeslundii, Porphyromonus gingivalis, Privotella intermedia, Streptococcus mutans were found to be susceptible to most of the extracts tested in the present study, only two plant extracts (Solanum panduriforme and Erythrina lysistemon) which were not active, were not considered for MIC, MBC and cytotoxicity. Euclea natalensis and Parinari curatellifolia showed best activity against Actinomyces israelii exhibiting an MIC of $1.6 \mathrm{mg} / \mathrm{ml}$. Little is known about Englerophytum magalismontanum included in this study, but other plants such as Euclea spp., Parinari spp. and Annona spp. Have been studied extensively on many pathogenic microorganisms.

According to Lall and Meyer (2000) water and acetone extracts of Euclea natalensis at concentration range of $0.1-6.0 \mathrm{mg} / \mathrm{ml}$ inhibited growth of the Bacillus spp. Micrococcus kristinae and Gram-negative bacteria Escherichia coli. Solanum panduriforme did not show any inhibitory activity against the microorganisms included in this study. However, the study conducted by Prozesky (2001) confirmed the antiplasmodial activity of some species of the genus Solanum. Previous studies have shown that the acetone and water extracts of Euclea natalensis possess antibacterial activity against Bacillus cereus, Bacillus pumilus, Bacillus subtilis and Staphylococcus aureus at concentrations ranging from 0.1 and $6.0 \mathrm{mg} / \mathrm{ml}$ (Lall and Meyer, 2000). Fresh roots samples of Euclea natalensis were tested against Streptococcus mutans, human saliva and periodontal pockets isolates and it was found that aerobic as well as anaerobic bacterial growth was suppressed in all instances (Stander and Van Wyk, 1991). 
Table 3

Mean MIC and MBC $(\mathrm{mg} / \mathrm{ml})$ results of six selected plants on oral microorganisms

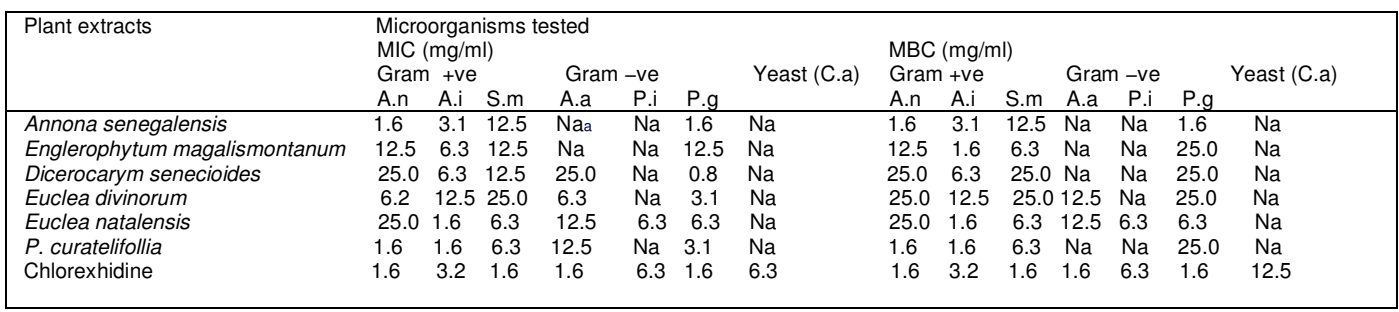

a Na: not active; A.n, Actinomyces naeslundii, A.i, Actinomyces israeli;; S.m, Streptococcus mutans; A.a, Actinobacillus actinomycetemcomitans; P.i, Privotella intermedia; P.g, Porphyromonus gingivalis; C.a, Candida albicans.

Table 4

Cytotoxicity $(\mu \mathrm{g} / \mathrm{ml})$ results and therapeutic index of six selected plants on Vero cell line

\begin{tabular}{|c|c|c|c|c|c|c|c|c|}
\hline \multirow[t]{3}{*}{ Species } & \multirow{2}{*}{\multicolumn{3}{|c|}{$\begin{array}{r}\text { IC50 }(\mu \mathrm{g} / \mathrm{ml}) \pm S . D . \\
\text { Gram +ve }\end{array}$}} & \multicolumn{4}{|c|}{ Microorganisms tested (therapeutic index) } & \multirow{3}{*}{ Yeast (C.a) } \\
\hline & & & & & \multicolumn{3}{|c|}{ Gram -ve } & \\
\hline & & A.n & A.i & S.m & A.a & P.i & P.g & \\
\hline Annona senegalensis & $71.0 \pm 4.3$ & 45 & 23 & 6 & $\mathrm{Naa}$ & $\mathrm{Na}$ & 45 & $\mathrm{Na}$ \\
\hline Bequaertiodendron magalismontanum & $98.8 \pm 2.7$ & 8 & 16 & 8 & $\mathrm{Na}$ & $\mathrm{Na}$ & 8 & $\mathrm{Na}$ \\
\hline Dicerocarym senecioides & $122.1 \pm 2.2$ & 5 & 19 & 10 & 5 & $\mathrm{Na}$ & 153 & $\mathrm{Na}$ \\
\hline Euclea divinorum & $142.3 \pm 4.6$ & 23 & 11 & 5.7 & 23 & $\mathrm{Na}$ & 46 & $\mathrm{Na}$ \\
\hline Euclea natalensis & $285.1 \pm 4.9$ & 11 & 16 & 45 & 23 & $\mathrm{Na}$ & 45 & $\mathrm{Na}$ \\
\hline Parinari curatellifolia & $92.3 \pm 3.0$ & 62 & 54 & 15 & $\mathrm{Na}$ & $\mathrm{Na}$ & 30 & $\mathrm{Na}$ \\
\hline Zelaralenone & $2.3 \pm 0.3$ & & & & & & & \\
\hline
\end{tabular}

${ }^{a} \mathrm{Na}$ not active at high concentration $(25.0 \mathrm{mg} / \mathrm{ml})$ tested, therefore no therapeutic index, A.n, Actinomyces naes/undii, A.i, Actinomyces israelii, S.m, Streptococcus mutans, A.a, Actinobacillus actinomycetemcomitans, P.i, Privotella intermedia, P.g, Porphyromonus gingivalis, C.a, Candida albicans.

It has also been reported earlier that the crude methanolic extract of dried twigs of Diospyros lycioides demonstrated preferential growth inhibitory activity against the oral pathogens Streptococcus mutans and Porphyromonus gingivalis at $1.25 \mathrm{mg} / \mathrm{ml}$ (Cai et al., 2000). Khan et al. (1978) reported the activity of ten methanolic plant extracts including Euclea natalensis which showed minimum inhibitory concentration ranging from $0.63 \mathrm{mg} / \mathrm{ml}$ to $5 \mathrm{mg} / \mathrm{ml}$ against Actinomyces viscosus, Streptococcus mutans and Candida albicans.

According to Samie et al. (2005) the MIC of Annona senegalensis was found to be greater than $>12 \mathrm{mg} / \mathrm{ml}$ where as in this study it was found to be $12.5 \mathrm{mg} / \mathrm{ml}$ when tested against Streptococcus mutans. A study by Khan et al. (1978), confirmed the MIC of the bark of Euclea natalensis on oral Candida albicans and Streptococcus mutans, the recorded MIC is 5.0 $\mathrm{mg} / \mathrm{ml}$ while in this study Streptococcus mutans was found to be susceptible at the MIC of $12.5 \mathrm{mg} / \mathrm{ml}$. Stander and Van Wyk (1991) have also reported the activity of Euclea natalensis against Streptococcus mutans.

All plant extracts showed moderate cytotoxicity on the Vero cell line. Fifty percent inhibitory concentration $\left(\mathrm{IC}_{50}\right)$ of all plants namely, Annona senegalensis, Englerophytum magalismontanum, Dicerocarym senecioides, Euclea divinorum, Euclea natalensis and $P$.

curatelifollia were found to range from 92.3 to $285.1 \mu \mathrm{g} / \mathrm{ml}$. The extracts on the cell lines showed a trend of an increase in cell viability at lower concentrations, with a decrease in cell viability as the concentration increases (Table 4). The $\mathrm{IC}_{50}$ value of the positive control Zelaralenone used in this study was found to be $2.3 \pm 0.3 \mu \mathrm{g} / \mathrm{ml}$.

The therapeutic index was determined as the cytotoxicity of plant extracts divided by the minimum inhibitory concentration value of the extracts on Vero cells (Lall et al., 2005). Values greater than 10 confirm the dose that can be administered inmost physiological systems. Annona senegalensis showed excellent therapeutic indexes greater than 20 on Actinomyces naes/undii, Actinomyces israelii and Porphyromonus gingivalis. The leaves of Euclea natalensis on Actinobacillus actinomycetemcomitans and Porphyromonus gingivalis showed an index of 23 and 45, respectively. The results documented in this study correspond with the reports of Hutchings et al. (1996), Van Wyk and Van Wyk (1997) and Van Wyk and Gericke (2000).

The results of this study provided an insight into the antibacterial properties of the extracts used traditionally for the prevention and treatment of oral problems and other ailments, as well as opportunity for selection of bioactive extracts for initial fractionation and further studies in antibacterial assays. 


\section{Acknowledgements}

Grant support by National Research Foundation and Division of Stomatological Research, Department of Community Dentistry.

\section{References}

Addy,M., 1986. Chlorhexidine compared with other locally delivered antimicrobials. Journal of Clinical Periodontology 13, 957-964.

Akpata, E.S., Akinrimisi, E.O., 1977. Antimicrobial activity of extracts from some African chewing sticks. Oral Surgery, Oral Medicine and Oral Pathology 44, 720-721.

Cai, L., Wei, G., Van der Bijl, P., Wu, C.D., 2000. Namibian chewing stick, Diospyros lycioides, contains antibacterial compounds against oral pathogens. Journal of Agricultural Food Chemistry 48, 909-914.

Cohen, M.A., Husband, M.D., Yoder, S.L., Gage, J.W., Roland, G.E., 1998. Bacterial eradication by clinafloxacin, $\mathrm{Cl}-990$, and ciprofloxacin employing MBC test, in-vitro time kill and in-vivo time-kill studies. Journal of Antimicrobial Chemotherapy 41, 605-614.

Eloff, J.N., 1998. A sensitive and quick microplate method to determine the minimal inhibitory concentration of plant extracts for bacteria. Planta Medica 64, 711-713.

Gründermann, L.J.M.M., Timmerman, M.F., ljserman, Y., 2000. Stain, plaque and gingivitis reduction by combining chlorhexidine and peroxyborate. Journal of Clinical Periodontology 27, 9-15.

Hadissa, T., Jean-Pierre, D., 2005. Use of medicinal plants for treatment of oral diseases in Burkina Faso. Journal of Ethnopharmacology 104, 68-78.

Homer, K.A., Manji, F., Beighton, D., 1990. Inhibition of protease activities of periodontopathic bacteria by extracts of plants used in Kenya as chewing sticks [mswaki]. Archives of Oral Biology 35, 421-424.

Hutchings, A., Haxton, S., Lewis, S.G., Cunningham, A., 1996. Zulu Medicinal Plants. An Inventory. University of Natal Press, Pietermaritzburg.

Khan, M.R., Mutasa, S.L., Ndaalio, G., Wevers, H., 1978. Antibiotic action of constituents of the roots of Euclea natalensis A.DC. Pakistan Journal of Scientific and Industrial Research 21, 197-199.

Lall, N., Meyer, J.J.M., 2000. Antibacterial activity of water and acetone extracts of the roots of Euclea natalensis. Journal of Ethnopharmacology 72, 313-316.

Lall, N.,Meyer, J.J.M.,Wang, Y., Bapela, N.B., Van Rensburg, Fourie, B., Franzblau, S.G., 2005. Characterization of intracellular activity of antitubercular constituents from roots of Euclea natalensis. Pharmaceutical Biology 43, 353-357.

Lewis, W.H., 1980. Plants used as chewing sticks. Journal of Preventive Dental 6, 71-73.

Lino, A., Deogracious, O., 2006. The in-vitro antibacterial activity of Annona senegalensis Securidacca longipendiculata and Steganotaenia araliacea-Ugandan medicinal plants. African Health Sciences 6, 31-35.

Mabogo, D.E.N., 1990. The ethnobotany of the Vhavenda. M.Sc. Thesis. University of Pretoria. 
Marsh, P., Martin, M., 1992. Oral Microbiology, 3rd ed. Chapman and Hall, London, pp. 131-136.

McFarland, J., 1907. The nephelometer: an instrument for estimating the number of bacteria in suspensions for calculating the opsonic index and vaccines. Journal of the American Medical Association 49, 1176.

Ndukwe, K.C., Lamikanra, A., Okeke, I.N., 2004. Antibacterial activity in plants used as chewing sticks in Africa. Drugs of the Future 29, 1221-1233.

Njenga, E., Van Vuuren, S.F., Viljoen,A.M., 2005. Antimicrobial activity of Eriocephalus species. South African Journal of Botany 71, 81-87.

Olsson, B., 1978. Efficiency of traditional chewing sticks in oral hygiene programs among Ethiopia schoolchildren. Communication of Dental Oral Epidemiology 6, 105.

Prozesky, E.A., Meyer, J.J.M., Louw, A.I., 2001. In-vitro antiplasmodial activity and cytotoxicity of ethnobotanically selected South African plants. Journal of Ethnopharmacology 76, 239-245.

Samaranayake, L.P., 2000. Essential Microbiology for Dentistry; with a Contribution by B.M. Jones; Foreword by Crispian Scully Edinburgh. Churchill Livingstone, New York.

Samie, A., Obi, C.L., Bessong, P.O., Namrita, L., 2005. Activity profile of fourteen selected medicinal plants from rural Venda community in South Africa against fifteen clinical bacterial species. African Journal of Biotechnology 4, 1443-1451.

Stander, I., Van Wyk, C.W., 1991. Tooth brushing with the roots of Euclea natalensis. Journal de Biologie Buccale 19, 167-172.

Van Oosten, M.A., Mikx, F.H., Rengi, H.H., 1987. Microbial and clinical measurement of periodontal pockets during sequential periods of non-treatment, mechanical debridement and metronidazole therapy. Journal of Clinical Periodontology 14, 197-204.

Van Wyk, B.-E., Gericke, N., 2000. Peoples Plants. Dental Care, pp. 205-213 (Chapter 12).

Van Wyk, B., Van Wyk, P., 1997. Field Guide to Trees of Southern Africa. Struik publishers, McKenzie Street, Cape Town.

Washington, J.A., 1981. Laboratory Procedures in Clinical Microbiology. SpringerVerlag, New York, NY.

Zheng, Y.T., Chan, W.L., Chan, P., Huang, H., Tam, S.C., 2001. Enhancement of the antiherpetic effect of trichosanthin by acyclovir and interferon. FEBS Letters 496, 139-142. 